\title{
Research on the Influence of Land Circulation on Farmers' Agricultural Mechanization Level
}

\author{
Jiquan Peng ${ }^{1, a, *}$, Caofeng Wei3,b ,Dongfang $\mathrm{Li}^{2, \mathrm{c}}$ and Haitao Wu ${ }^{1, d}$ \\ ${ }^{1}$ School of Business Administration, Zhongnan University of Economics and Law, Wuhan, Hubei, China \\ ${ }^{2}$ School of Public Administration, Zhongnan University of Economics and Law, Wuhan, Hubei, China \\ ${ }^{3}$ School of Foreign studies, Anhui Normal University, Wuhu, Anhui,China

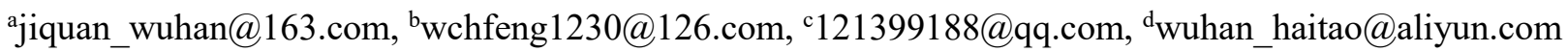 \\ *corresponding author
}

Keywords: Land Circulation, Farmers, Level of Agricultural Mechanization

\begin{abstract}
Based on the perspective of inward land circulation and outward land circulation, this paper uses the field survey data of 1,682 farmers in Hubei Province to analyze the impact of land circulation on agricultural mechanization of farmers. The results show that "inward land circulation" will significantly increase the level of agricultural mechanization and "outward land circulation" will significantly reduce the level of agricultural mechanization. In terms of the type of land circulationred, Inward land circulation dryland area is more impactful on the level of agricultural mechanization than Inward land circulation paddy field area; Onward land circulation dryland area is more impactful on the level of agricultural mechanization than Onward land circulation paddy field area. The robustness test further confirmed the above results. The age of head of household, labor training ratio, and the proportion of unhealthy people have a significant negative effect on the level of agricultural mechanization; average years of labor force education and the number of types of crops planted have a significant positive impact on the level of agricultural mechanization; the plains, compared to the non-plain regions, have a higher level of agricultural mechanization.
\end{abstract}

\section{Introduction}

Since the Reform and Opening up, as the Central Government has continuously increased the investment in infrastructure and optimized and upgraded the industrial structure, China's agricultural economy has developed rapidly. In 2016, China's agricultural output value reached 11.47 trillion yuan, and the average annual growth rate in the last ten years was as high as $13.4 \%$. The rapid growth of the agricultural economy has not only ensured the stability of rural society, but also increased the income of peasants and improved the lives of peasants. However, this does not mean that China has completely shaken off the traditional agricultural stage and entered the stage of modern agricultural development. The important reason is that China has not yet fully realized agricultural mechanization. Before the $21 \mathrm{st}$ century, the development of China's agricultural mechanization was relatively slow. During the period between 1978 and 2000, the level of comprehensive mechanization for agricultural cultivation in China rose from $19.66 \%$ to $32.47 \%$. After entering the 21 st century, China's agricultural mechanization has developed rapidly. The level of comprehensive mechanization of agricultural cultivation in China has increased from $32.18 \%$ in 2001 to $65.32 \%$ in 2017 . This is mainly due to the large number of rural laborers working outside and the Chinese government's increasing Agricultural machinery application policy support efforts. However, as far as the level of comprehensive mechanization of agricultural farming in China is concerned, there is a wide gap between China and the developed countries, such as the United States and Japan, has a wide gap. Therefore, how to speed up the improvement of China's agricultural mechanization level is an issue that deserves further study.

There are two opposing views on the scale of land and the use of farmer household 
mechanization technology. Since agricultural technology adopts the requirements of "intensive pattern" and "scale" for land (Deng Hongtu and Cui Baomin, 2007), As a result, there is a school of thought that if we want to promote China's agricultural mechanization, we need to focus our existing scattered farmland on our operations. (Cao Guangqiao and Zhang Zongyi, 2008; Xu Shiyan and Li Shibao, 2009; Cai Jian and Shao Shuang et al., 2016). Contrary to the above ideas, some scholars believe that because of the leaseability of agricultural machinery, the fine-grained land of small peasant households does not affect the development of agricultural mechanization. The "cross-regional operation service for agricultural machinery" can concentrate thousands of small-scale farmers into one large farm and can also achieve modern large-scale production (Xue Liang, 2008; Cao Lianghe, Hu Jiliang, 2010; Hu Xinyan, Yang Xiaoying, etc. 2016).

The above two contradictory viewpoints could be perplexing. The main reason for the above problems is that when scholars analyze the impact of land circulation on farmer household mechanization, they simply study the impact of inward land circulation on the use of agricultural machinery. Rarely has the impact of land circulation be considered. If the outward land circulation has no impact on the adoption of agricultural technology, it is very likely that inward land circulation does not have any impact on the adoption of agricultural technology. Therefore, will land circulation affect agricultural machinery adoption? The scientific answer to this question will be conducive to the formulation of China's agricultural land policy and the development of agricultural mechanization. Based on this, this paper will study the impact of land circulation on agricultural mechanization from the perspective of inward land circulation and outward land circulation

\section{Data sources and variable selection}

\subsection{Sources of data}

The research data of this paper comes from field survey data of farmers in Hubei Province in 2016. The survey covers the basic information of family population, family material assets, family social assets, loan behavior, household production and operation, and farmland circulation behavior. Agricultural policy awareness and so on. In order to ensure a representative sample selection, the survey site selected five counties and cities such as Yingshan County, Qichun County, Shashi City, Yangxin County and Laohekou City, which can represent the eastern, central and western parts of Hubei Province to some extent. Using random sampling methods, 5 townships were selected in each county, 2 villages were selected from each township, 35 households were selected from each village, 1750 households were investigated, 68 invalid samples were removed, and a total of 1682 valid samples were obtained. .

\subsection{Variable selection}

(1) The level of agricultural mechanization. To explore the influencing factors of agricultural mechanization, the first is to determine the standards of agricultural mechanization. At present, there are mainly three methods for measuring the level of agricultural mechanization, namely, the total power of agricultural machinery, the net value of agricultural machinery, and the comprehensive mechanization rate of agricultural crop cultivation. The first two cannot accurately measure the true level of agricultural mechanization. First, with the development of the agricultural machinery industry, the decisive role of the power level in the ability of the agricultural machinery operation level is weakening, and many small power machinery can also exert high-performance operational capabilities; Because cross-regional operations of agricultural machinery have become more popular in China, the total power of the agricultural machinery in the region cannot fully represent the level of agricultural mechanization; the third reason is that it is difficult to obtain data on the total agricultural machinery power at the household level. This paper mainly uses the Ministry of Agriculture's measure of mechanization, that is, the comprehensive mechanization rate of crop cultivation. The calculation method is a weighted average of the tillage rate, the machine sowing rate and the machine yield (the weights are $0.4,0.3,0.3$ respectively).

(2) Land circulation. Land circulation is the key explanatory variable of this paper, which is mainly 
divided into inward land circulation area and outward land circulation area. The types of land further divided into paddy fields and dry lands. Finally, this paper forms six types of land circulation variables. In order to consider the robustness of the model, six kinds of dummy variables with or without land circulation were regenerated according to whether the farmer had land circulation

(3) Other control variables. The age of the householder. The head of the household is an important role in family decision-making, and the characteristics of the head of household will affect the choice and expenditure of agricultural households on agricultural machinery services. In general, as the age of the head of the household increases, the likelihood that the head of the household will go out to work will be reduced, and more time will be devoted to agricultural production and management. The use of the farmer's machinery may also be reduced. The average number of years of schooling education. The higher the educational level of the family's workforce, the higher the opportunity cost of farming at home. As far as China's rural areas are concerned, migrant employment income has become the main source of income for rural families. When the family laborers go out to work, the degree of mechanical use of their family land tends to be higher. Labor training ratio. The higher the percentage of family laborers who receive professional training, the less farmer households will engage in agricultural production and management activities based on the consideration of comparative benefits, and the willingness and input cost of agriculture will be reduced. The proportion of unhealthy people in the family. The higher the proportion of unhealthy members of the family, the lower the household income may be. Given the high cost of agricultural machinery, farmers will choose to cultivate their land more. Crop planting species. The more kinds of crops planted, the more diversified the farmer's agricultural production, the higher the degree of farmer's use of land, and in order to ensure the best growing time of crops in different seasons, farmers tend to use agricultural machinery to shorten the time of sowing, planting, and harvesting. Terrain characteristics. Topographical features have a very important influence on the use of agricultural machinery. In general, the convenience of agricultural machinery operations is higher in plain areas than in hills or mountains.

Table 1 Variable descriptive statistics

\begin{tabular}{|c|c|c|c|c|c|}
\hline Variable & Variable definitions & Mean & Std. Dev. & Min & Max \\
\hline jxhsp & Mechanization level & 0.6360 & 0.2990 & 0 & 1 \\
\hline zrmj & Inward land circulation area & 2.3139 & 14.2305 & 0 & 300 \\
\hline zrst & Inward land circulation paddy field area & 1.7654 & 13.5052 & 0 & 300 \\
\hline zrhd & Inward land circulation dryland area & 0.6452 & 4.5275 & 0 & 70 \\
\hline zcmj & Onward land circulation area & 0.5884 & 2.5425 & 0 & 28 \\
\hline zcst & Onward land circulation paddy field area & 0.4649 & 2.2390 & 0 & 28 \\
\hline zchd & Onward land circulation dryland area & 0.1452 & 1.1789 & 0 & 21 \\
\hline ifzr & Whether it is transferred in, yes $=1 ;$ no $=0$ & 0.1254 & 0.3314 & 0 & 1 \\
\hline ifzrst & $\begin{array}{l}\text { Whether the paddy field is transferred in, yes }=1 \text {; } \\
\qquad \text { no }=0\end{array}$ & 0.1013 & 0.3019 & 0 & 1 \\
\hline ifzrhd & Whether dry land is transferred in, yes $=1 ;$ no $=$ & 0.0725 & 0.2595 & 0 & 1 \\
\hline ifzc & Whether it is transferred out, yes $=1 ;$ no $=0$ & 0.1059 & 0.3078 & 0 & 1 \\
\hline ifzcst & $\begin{array}{l}\text { Whether the paddy field is transferred out, yes }=1 \text {; } \\
\qquad \text { No }=0\end{array}$ & 0.0875 & 0.2827 & 0 & 1 \\
\hline ifzchd & $\begin{array}{l}\text { Whether the dry land is transferred out, yes }=1 \text {; No } \\
\qquad=0\end{array}$ & 0.0322 & 0.1767 & 0 & 1 \\
\hline hage & The age of head of household & 55.9931 & 11.0335 & 0 & 84 \\
\hline ljyns & $\begin{array}{c}\text { Average years of labor force education }=\text { actual } \\
\text { value }\end{array}$ & 6.9071 & 3.7590 & 0 & 13.5 \\
\hline b train & Labor training ratio & 0.0928 & 0.1904 & 0 & 1.25 \\
\hline
\end{tabular}


Table 1, cont.

\begin{tabular}{cccccc}
\hline b_bjkrs & Proportion of unhealthy people= actual value & 0.1661 & 0.3154 & 0 & 1 \\
crops & The number of types of crops planted & 2.0840 & 1.4476 & 0 & 8 \\
terrain2 & Terrain characteristics,plain = 1; non-plain $=0$ & 0.3326 & 0.4714 & 0 & 1 \\
\hline
\end{tabular}

\section{The empirical model and regression results}

\subsection{The basic model}

In this paper, the survey data of 1,682 farmer households in Hubei Province are used as research samples to construct a quantitative regression model as shown in (1): to examine how land circulation affects the agricultural mechanization level of farm households: ${ }_{i}=\alpha_{0}+\beta_{0} x_{i}+\sum \gamma_{i} Z_{i}+\mu_{i}$

(1) In the formula, the subscript i denotes a single farmer, $y_{i}$ denotes the farmer's agricultural mechanization level index, and the comprehensive mechanization rate of farm crops is the main indicator. $x_{i}$ is an indicator of land circulation, using the actual area of land circulation as the main indicator. . In addition, the use of land flow transitions was used as a model robustness test indicator. $\mathrm{Z}$ is the other control variables, including the age of the head of the household, the average education level of the labor force, the proportion of labor training, the proportion of unhealthy people in the family, the crop planting type and topographic characteristics. ${ }^{\mu_{i}}$ is the random disturbance term, and $\alpha_{0}, \beta_{0}, \gamma_{i}$ is the parameter to be estimated, where $\beta_{0}$ is the parameter that is the interest of this article.

\subsection{Basic results and analysis}

Table 2 shows the regression results of the basic model. The key explanatory variables for the columns (1)-(6) are Inward land circulation area, Inward land circulation paddy field area, Inward land circulation dryland area, Onward land circulation area, Onward land circulation paddy field area, Onward land circulation dryland area. From the results of the regression, "Inward land circulation area" has a significant positive impact on the level of agricultural mechanization, and "Onward land circulation area" has a significant negative impact on the level of agricultural mechanization. From the point of view of land circulation area variable, the impact of "Inward land circulation area" is between "Inward land circulation paddy field area" and "Inward land circulation dryland area", and the impact of "Inward land circulation paddy field area" is significantly lower than the impact of "Inward land circulation dryland area". The possible reason is that the degree of mechanical use of paddy fields has been higher than that of dry land in the past. The scale operation of dry lands can also improve the level of agricultural mechanization. From the perspective of the land area transferred out, the impact of "Onward land circulation area" is lower than "Onward land circulation paddy field area" and "Onward land circulation dryland area", and the impact of "Onward land circulation dryland area" is greater than the impact of "Onward land circulation paddy field area", further corroborating the above. In summary, "Onward land circulation area" has a significant negative impact on the farmer's agricultural mechanization level. "Onward land circulation area" has a significant negative impact on the farmer's agricultural mechanization level, and the impact of land circulation in drylands is greater. So far, this article has proved that land circulation does have a significant impact on the farmer's level of agricultural mechanization.

From the perspective of control variables, "The age of head of household" has a significant negative impact on the level of agricultural mechanization. This may be due to the fact that as the age of the household head increases, the possibility of migrant workers is reduced and there will be more time to engage in agricultural production and management activities. The use of agricultural machinery will not be very high. "Average years of labor force education" has a significant positive effect on the level of agricultural mechanization. The reason may be that the higher the education level of the family labor force, the greater the possibility of engaging in non-agricultural production and management activities, the higher the opportunity cost of engaging in agriculture, and the upper 
farmers will rationally choose to use machinery instead of labor. "Labor training ratio " has a significant negative impact on the level of agricultural mechanization. This is because farmers who have undergone professional training will increase their likelihood of engaging in non-agricultural production activities and their willingness to engage in agriculture will decrease. Compared with meagre agricultural income, More funds of farmers will be invested in non-agricultural business activities. "Proportion of unhealthy people" has a significant negative impact on the level of agricultural mechanization. The probable reason is that the greater the proportion of unhealthy people in the family, the smaller the number of households that can participate in the labor force, and the relative reduction in family income, for considering the high cost of using agricultural machinery, such families often choose to use labor to replace machinery. "The number of types of crops planted" has a significant positive effect on the level of agricultural mechanization. The possible reason is that the more types of crops planted by farmers, in order to ensure that crops do not miss a good planting time, farmers tend to choose more convenient mechanical operations to reduce the time spent on farming, planting, and harvesting. In terms of "terrain characteristic", compared with non-plain areas, the level of farmer's agricultural mechanization in the plain areas will be higher. This is basically in line with reality.

Table 2 The regression results of the benchmark model (key explanatory variable: land circulation area)

\begin{tabular}{|c|c|c|c|c|c|c|}
\hline \multirow{2}{*}{ Variables } & zrmj & zrst & zrhd & $\mathrm{zcmj}$ & $\mathrm{zcst}$ & zchd \\
\hline & (1) & (2) & (3) & (4) & $(5)$ & $(6)$ \\
\hline \multirow[t]{2}{*}{ transfer } & $0.0025^{* * *}$ & $0.0022 * * *$ & $0.0049 *$ & $-0.0103 *$ & $-0.0118 *$ & $-0.0152 * * *$ \\
\hline & $(0.0006)$ & $(0.0005)$ & $(0.0025)$ & $(0.0053)$ & $(0.0069)$ & $(0.0056)$ \\
\hline \multirow[t]{2}{*}{ hage } & $-0.002 * *$ & $-0.0021 * *$ & $-0.0019^{* *}$ & $-0.0020 * *$ & $-0.0021 * *$ & $-0.002 * *$ \\
\hline & $(0.0009)$ & $(0.0009)$ & $(0.0009)$ & $(0.0009)$ & $(0.0009)$ & $(0.0009)$ \\
\hline \multirow[t]{2}{*}{ ljyns } & $0.0089^{* * *}$ & $0.009 * * *$ & $0.0097 * * *$ & $0.0094 * * *$ & $0.0091 * * *$ & $0.0098 * * *$ \\
\hline & $(0.0027)$ & $(0.0027)$ & $(0.0027)$ & $(0.0027)$ & $(0.0027)$ & $(0.0027)$ \\
\hline \multirow[t]{2}{*}{ b_train } & $-0.190 * * *$ & $-0.190 * * *$ & $-0.180 * * *$ & $-0.178 * * *$ & $-0.175 * * *$ & $-0.184 * * *$ \\
\hline & $(0.0465)$ & $(0.0465)$ & $(0.0473)$ & $(0.0469)$ & $(0.0473)$ & $(0.0471)$ \\
\hline \multirow[t]{2}{*}{ b_bjkrs } & $-0.0823 * * *$ & $-0.0843 * * *$ & $-0.0824 * * *$ & $-0.0871 * * *$ & $-0.0872 * * *$ & $-0.0857 * * *$ \\
\hline & $(0.0283)$ & $(0.0283)$ & $(0.0284)$ & $(0.0282)$ & $(0.0282)$ & $(0.0283)$ \\
\hline \multirow[t]{2}{*}{ crops } & $0.0358 * * *$ & $0.0365 * * *$ & $0.0363 * * *$ & $0.0340 * * *$ & $0.0341 * * *$ & $0.0363 * * *$ \\
\hline & $(0.0067)$ & $(0.0068)$ & $(0.0069)$ & $(0.0070)$ & $(0.0070)$ & $(0.0068)$ \\
\hline \multirow[t]{2}{*}{ 1.terrain2 } & $0.130 * * *$ & $0.128 * * *$ & $0.132 * * *$ & $0.134 * * *$ & $0.136 * * *$ & $0.128 * * *$ \\
\hline & $(0.0206)$ & $(0.0207)$ & $(0.0208)$ & $(0.0206)$ & $(0.0206)$ & $(0.0207)$ \\
\hline \multirow[t]{2}{*}{ Constant } & $0.335 * * *$ & $0.340 * * *$ & $0.324 * * *$ & $0.347 * * *$ & $0.351 * * *$ & $0.336 * * *$ \\
\hline & $(0.0636)$ & $(0.0640)$ & $(0.0637)$ & $(0.0644)$ & $(0.0643)$ & $(0.0642)$ \\
\hline Observations & 869 & 869 & 869 & 869 & 869 & 869 \\
\hline $\mathrm{R}$-squared & 0.146 & 0.141 & 0.137 & 0.139 & 0.139 & 0.135 \\
\hline
\end{tabular}

Note: * indicates that the variable is statistically significant at the $10 \%$ level, $* *$ indicates that the variable is statistically significant at the $5 \%$ level, *** indicates that the variable is statistically significant at the $1 \%$ level.

\subsection{Robustness test}

In order to ensure the robustness of the model, this paper chooses whether the land is transferred to replace the land circulation area in the benchmark model. The key explanatory variables in columns (1)-(6) are whether it is transferred in, whether the paddy field is transferred in, whether dry land is transferred in, whether it is transferred out, whether the paddy field is transferred out, and whether the dry land is transferred out, the regression results of the robustness test are shown in Table 3. From the perspective of land circulation, the farmer households who have been transferred to the 
land will have a higher level of agricultural mechanization than those who have not been transferred to the land, and they are significant at the level of 1\%; farmers who have transferred to paddy fields will have higher levels of agricultural mechanization than farmers who have not been transferred to paddy fields. However, the results are not significant; farm households that have been transferred to drylands have higher levels of agricultural mechanization than households that have not been transferred to drylands, and the results are not significant. Judging from whether or not the land has been transferred, the farmer households that have transferred out of the land will have lower agricultural mechanization levels than the farmer households that have not transferred the land, and they are significantly at the level of $1 \%$; farmers who have transferred out of paddy fields have lower levels of agricultural mechanization than those who have not been transferred out of paddy fields, and they are significant at the 1\% level.. Farmers who had transferred out of dry lands had lower levels of agricultural mechanization than those who did not transfer out of dry land. The above regression results show that land circulation will promote the level of agricultural mechanization, and land circulation will reduce the level of agricultural mechanization. The regression results of the robustness test are basically consistent with the regression results of the benchmark model, and the regression results of other control variables are also basically the same. Therefore, the results of the research and analysis in this paper are robust and the conclusions are true and credible.

Table 3 Regression results of the robustness test (key explanatory variable: land circulation)

\begin{tabular}{ccccccc}
\hline \multirow{2}{*}{ Variables } & ifzr & ifzrst & ifzrhd & ifzc & ifzcst & ifzchd \\
\cline { 2 - 6 } & $(1)$ & $(2)$ & $(3)$ & $(4)$ & $(5)$ & $(6)$ \\
\hline iftransfer & $0.0835^{* * *}$ & 0.0442 & 0.0024 & $-0.129 * * *$ & $-0.153^{* * *}$ & $-0.154^{* * *}$ \\
& $(0.0300)$ & $(0.0332)$ & $(0.0403)$ & $(0.0327)$ & $(0.0350)$ & $(0.0468)$ \\
hage & $-0.0021^{* *}$ & $-0.0021^{* *}$ & $-0.0021^{* *}$ & $-0.002^{* *}$ & $-0.002^{* *}$ & $-0.002^{* *}$ \\
& $(0.0009)$ & $(0.0009)$ & $(0.0009)$ & $(0.0009)$ & $(0.0009)$ & $(0.0009)$ \\
ljyns & $0.0093^{* * *}$ & $0.0095^{* * *}$ & $0.0097^{* * *}$ & $0.0090^{* * *}$ & $0.0088^{* * *}$ & $0.0097^{* * *}$ \\
& $(0.0027)$ & $(0.0027)$ & $(0.0027)$ & $(0.0028)$ & $(0.0027)$ & $(0.0027)$ \\
b_train & $-0.188^{* * *}$ & $-0.187^{* * *}$ & $-0.184^{* * *}$ & $-0.176^{* * *}$ & $-0.173^{* * *}$ & $-0.185^{* * *}$ \\
& $(0.0471)$ & $(0.0471)$ & $(0.0473)$ & $(0.0465)$ & $(0.0463)$ & $(0.0473)$ \\
b_bjkrs & $-0.0816^{* * *}$ & $-0.0863^{* * *}$ & $-0.0851^{* * *}$ & $-0.0845^{* * *}$ & $-0.0905^{* * *}$ & $-0.0825^{* * *}$ \\
& $(0.0281)$ & $(0.0284)$ & $(0.0283)$ & $(0.0280)$ & $(0.0281)$ & $(0.0283)$ \\
crops & $0.0345^{* * *}$ & $0.0362^{* * *}$ & $0.0376^{* * *}$ & $0.0314 * * *$ & $0.0311^{* * *}$ & $0.0350^{* * *}$ \\
& $(0.0068)$ & $(0.0068)$ & $(0.0069)$ & $(0.0071)$ & $(0.0070)$ & $(0.0069)$ \\
1.terrain2 & $0.130^{* * *}$ & $0.128^{* * *}$ & $0.129^{* * *}$ & $0.126^{* * *}$ & $0.130^{* * *}$ & $0.125^{* * *}$ \\
& $(0.0207)$ & $(0.0208)$ & $(0.0208)$ & $(0.0207)$ & $(0.0206)$ & $(0.0207)$ \\
Constant & $0.336^{* * *}$ & $0.338^{* * *}$ & $0.337 * * *$ & $0.361^{* * *}$ & $0.363^{* * *}$ & $0.345^{* * *}$ \\
& $(0.0638)$ & $(0.0642)$ & $(0.0640)$ & $(0.0647)$ & $(0.0641)$ & $(0.0636)$ \\
Observations & 869 & 869 & 869 & 869 & 869 & 869 \\
R-squared & 0.14 & 0.134 & 0.132 & 0.148 & 0.151 & 0.14 \\
\hline
\end{tabular}

Note: * indicates that the variable is statistically significant at the $10 \%$ level, $* *$ indicates that the variable is statistically significant at the $5 \%$ level, *** indicates that the variable is statistically significant at the $1 \%$ level.

\section{Conclusions and recommendations}

Based on the field survey data of 1,682 farmers in Hubei, this paper analyzes the impact of land circulation on the level of agricultural mechanization from the perspective of "Inward land circulation" and "Outward land circulation". The results of the study indicate that "Inward land circulation" will significantly increase the level of agricultural mechanization. This will significantly reduce the level of agricultural mechanization. From the perspective of the type of land circulationred, "Inward land circulation dryland area" has a greater impact on the improvement of 
agricultural mechanization than on "inward land circulation paddy field area". "Onward land circulation paddy field area" and "Onward land circulation dryland area" have a greater impact on the reduction of agricultural mechanization. Robustness test further confirms the above results. The age of head of household, labor training ratio, and proportion of unhealthy people have a significant negative effect on the level of agricultural mechanization; average years of labor force education and The number of types of crops planted have a significant positive impact on the level of agricultural mechanization; the plains are compared to the non-plain regions, and their agriculture The level of mechanization will be higher. Therefore, land circulation does affect the level of agricultural mechanization. Moderate land scale operation can increase the level of agricultural mechanization of farmers, and in particular increase the scale of dry land, the effect being more pronounced. The government should further improve the rules and regulations on land circulation, increase the human capital of rural labor through various forms of education, encourage farmers to adopt diversified planting patterns, pay attention to rural non-healthy people, increase the level of agricultural mechanization, and promote agricultural modernization.

\section{Acknowledgement}

This paper belongs to the grant of National Natural Science Foundation of China's project Life Cycle, Livelihood Strategy and Poverty Dynamics of Peasants, project number: (71273281); The Key Research Base of Humanities and Social Science of Hubei Province - The Open Fund Project of Rural Community Research Center of Hubei University A Study on the Impact of Urbanization on the changes of Income Structure in Urban-rural Households, project number: (013044039); The Innovational Education Project of the Doctor of Zhongnan University of Economics and Law A Study on the Impact of Urbanization on Urban-Rural Income Inequality, project number: (2017B1011); 2018 Yangtze River University Social Assistance Research Center Project, project number: (18JZ03).

\section{References}

[1] Cai Jian, Shao Shuang, Liu Wenyong. Research on the relationship between land circulation and agricultural machinery application-Analysis of maize mechanized harvest based on three provinces of Hebei, Henan and Shandong[J]. Shanghai Economic Research, 2016(12):89-96 .

[2] $\mathrm{Hu}$ Xinyan, Yang Xiaoying, Luo Jintao. Confirmation of Rights and Farmland Circulation: Theoretical Disagreements and Research Inspiration [J]. Research in Finance and Trade, 2016, 27(02): 67-74.

[3] Cao Yang, Hu Jiliang. Agricultural Mechanization Under Land Contracting System in China: Based on Survey Data of 17 Provinces (Regions, Cities) in China[J]. Rural Economy in China, 2010(10):57-65+76.

[4] Xu Shiyan, Li Shibao. Analysis of Factors Affecting Farmers' Agricultural Technology Demand in China at the Present Stage [J]. Agricultural Technology \& Economy, 2009(04):42-47.

[5] Cao Guangqiao, Zhang Zongyi. Research on the Influencing Factors of Farmers Adopting Conservation Tillage[J]. Journal of Agricultural Economics,2008(08):69-74.

[6] Xue Liang. Looking at the modernization of agriculture with Chinese characteristics from the scale of agricultural operations[J]. Journal of Agricultural Economics, 2008(06):4-9+110.

[7] Deng Hongtu, Cui Baomin. Nature of China's Farmland Property Rights in Institutional Changes: A Historical Analysis Perspective [J]. Nankai Economic Research, 2007(06): 118-141. 